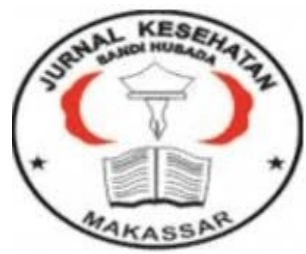

\author{
Jurnal Ilmiah Kesehatan Sandi Husada \\ hhttps://akper-sandikarsa.e-journal.id/JIKSH \\ Vol 11, No, 1, Juni 2020, pp;365-371 \\ p-ISSN: 2354-6093 dan e-ISSN: 2654-4563 \\ DOI: $10.35816 /$ jiskh.v10i2.291
}

\title{
Hubungan Kondisi Lingkungan Rumah dengan Keberadaan Jentik Ae.Aegypti
}

The Relationship between Home Environment Conditions and the Existence of Ae.Aegypti

\section{Tusy Triwahyuni' ${ }^{1}$, Ismalia Husna² ${ }^{2}$ Devita Febriani Putri ${ }^{3}$, Miya Medina ${ }^{4}$ \\ ${ }^{1}$ Departemen Parasitologi Fakultas Kedokteran Universitas Malahayati \\ 2 Departemen Parasitologi Fakultas Kedokteran Universitas Malahayati \\ ${ }^{3}$ Departemen Parasitologi Fakultas Kedokteran Universitas Malahayati \\ ${ }^{4}$ Mahasiswa Program Studi Kedokteran Universitas Malahayati}

\section{Artikel info}

\section{Artikel history:}

Received; 20 April 2020

Revised: 28 April 2020

Accepted; 05Mei 2020

\begin{abstract}
Abstrak
Latar Belakang: Demam Berdarah Dengue adalah penyakit yang disebabkan oleh virus serotipe 1-4 (DEN-1, DEN-2, DEN-3, DEN-4). Masuknya virus ke dalam tubuh manusia sampai menimbulkan gejala memiliki jangka waktu 3-5 hari. Tujuan Penelitian: Mengetahui hubungan kondisi lingkungan rumah dengan keberadaan jentik nyamuk Ae. aegypti di wilayah kerja puskesmas Way Kandis Bandar Lampung. Metode Penelitian: Penelitian ini menggunakan desain studi cross sectional. Sampel pada penelitian ini sebanyak 100 sampel. Teknik sampling yang digunakan adalah Total sampling. Instrumen yang digunakan adalah lembar observasi dan kuesioner. Analisa data yang digunakan adalah chi-square test. Hasil: Hasil analisis statistik menggunakan uji Chi-square menunjukan variabel yang berhubungan dengan keberadaan jentik Ae.aegypti adalah genangan air ( $P$ value $=0,039 ; O R=2,729)$. Variabel yang tidak berhubungan antara lain keberadaan tanaman hias, keberadaan jarak antar rumah, kebiasaan menggantung pakaian, keberadaan kawat kasa. Kesimpulan: Genangan air merupakan kondisi lingkungan rumah yang memiliki hubungan dengan keberadaan jentik Ae. aegypti di kelurahan Way Kandis sedangkan keberadaan tanaman hias, keberadaan jarak antar rumah, kebiasaan menggantung pakaian, keberadaan kawat kasa tidak memiliki hubungan dengan keberadaan jentik Ae. aegypti di kelurahan Way Kandis.
\end{abstract}

\begin{abstract}
Abstrack
Background: Dengue hemorrhagic fever is a disease caused by serotype 1-4 viruses (DEN-1, DEN-2, DEN-3, DEN-4). The entry of the virus into the human body to cause symptoms has a period of 3-5 days. Goals: Knowing the relationship between home environment conditions and the existence of larva Ae.aegypti at puskesmas of way kandis bandar lampung. Method: This study was conducted using cross sectional study design. The samples of
\end{abstract}


this study were 100 samples. The sampling technique in this study is total sampling. The instrument used was the observation sheet and questionnaire. The analyzed being used was the chi-square test. Result: The result of statistic analysis using Chi-square test suggest that the variables related to the larva Ae. aegypti is puddle ( $P$ value $=0,039 ; O R=2,729)$. Unrelated variables include the ornamental plants, distances between homes, hanging clothes, wire netting. Conclusion: puddle is the variables in home environment conditions that related with larva Ae.aegypti in Way Kandis region. are unrelated variabel relationship between home environment conditions and the existence of larva ae.aegypti in region Way Kandis.

Keywords:

Ae.aegypti;

$D B D$;

Larva;

Home environment
Coresponden author:

Email: medinamiyaxn@gmail.com

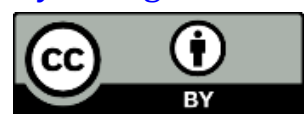

artikel dengan akses terbuka dibawah lisensi CC BY -4.0

\section{Pendahuluan}

Demam Berdarah Dengue (DBD) adalah penyakit yang disebabkan oleh virus serotipe 1-4 (DEN-1, DEN-2, DEN-3, DEN-4). Orang yang tinggal di daerah endemik dapat tertular oleh empat virus DBD sepanjang waktu dikarenakan empat serotipe ini tidak menjadikan kekebalan protektif silang. Penularan virus dibantu oleh spesies Ae aegypti dan Ae. albopictus, spesies tersebut merupakan hewan pembawa penyakit (vektor) primer dari penyakit DBD (Cecep, 2011). Pada tahun 2017 Provinsi Bandar Lampung menduduki urutan ke-7 kasus DBD tertinggi dengan jumlah 3 Ribu kasus, dan ditemukan 9 kasus DBD dengan keterangan kematian (Dinkes Lampung, 2015). Berdasarkan hasil statistik oleh BPS (Badan Pusat Statistik) terdapat 138 kasus DBD di kecamatan Way Kandis yang menempatkan Way Kandis pada posisi teratas dan terbanyak untuk kasus DBD di Kota Bandar Lampung (Dinkes Lampung, 2018).

Faktor yang berkaitan dengan penyebaran penyakit DBD, yaitu agent, host, dan environment. Ketika dari segi lingkungan berubah maka akan mempengaruhi host, akibatnya penyakit akan datang secara individu dan menyeluruh. Agent (datangnya penyakit) DBD disebabkan oleh 4 serotipe virus (DEN-1, DEN-2, DEN-3, DEN-4) yang dibawa oleh nyamuk betina Ae. aegypti. Masuknya virus ke dalam tubuh manusia sampai menimbulkan gejala memiliki jangka waktu 3-5 hari (Dermala,2012).

Vektor DBD ialah nyamuk Ae. aegypti, nyamuk ini suka hinggap di tempat yang gelap dan lembab (Rima, 2017). Manusia adalah host pertama yang terpapar virus DBD. Virus tersebut berada dalam darah 4-7 hari sebelum timbulnya gejala (Kusumawati, 2017). Faktor lingkungan yang tidak terurus seperti banyaknya tanaman rimbun di pekarangan, kaleng-kaleng bekas, genangan air disekitar rumah menjadikan tempat tersebut tempat yang disenangi oleh nyamuk untuk hidup dan berkembang biak (Cecep,2011).

Menurut penelitian Siahaan, etal,(2019) "Studi Kepadatan Jentik Nyamuk Di Kelurahan Tebing Tinggi Kecamatan Tebing Tinggi Kabupaten Tanjung Jabung Barat Jambi Tahun 2019" Bahwa pada pot bunga di luar rumah tidak ditemukan jentik Ae.agypti, tetapi jentik banyak ditemukan pada drumb bekas dikarenakan memiliki penampungan air lebih 
banyak. Menurut penelitian Jacob dkk (2015) yang menyatakan bahwa nyamuk Ae. aegypti mampu hidup di genangan air jernih.

Nyamuk Ae aegypti betina memiliki jarak terbang perhari sekitar 30-50 meter, namun jarak terbangnya tergantung pada tersedianya tempat untuk bertelur. Jika tempat bertelur ada di sekitar rumah, maka nyamuk tidak terbang jauh. Rata rata kemampuan terbang nyamuk betina adalah 40 meter dan maksimal 100 meter (Cecep, 2011). Menurut Nilawati (2015) dalam " Pelaksanaan 3M dengan keberadaan jentik Ae.aegypti di wilayah Kerja Puskesmas Bekasi" tidak terdapat hubungan yang bermakna antara kebiasaan menggantung pakaian dengan keberadaan jentik Ae.aegypti dan tidak terdapat hubungan yang bermakna antara keberadaan kawat kasa dengan keberadaan jentik Ae.aegypti.

\section{Metode}

Penelitian ini menggunakan desain studi cross sectional. Sampel pada penelitian ini sebanyak 100 sampel. Teknik sampling yang digunakan adalah Total sampling. Instrumen yang digunakan adalah lembar observasi dan kuesioner. Analisa data yang digunakan adalah chi-square test.

\section{Hasil dan Pembahasan}

\section{Tabel 1. Analisis keberadaan tanaman hias di lingkungan rumah dengan keberadaan jentik Ae.aegypti \\ Sumber : Data Primer}

Hasil uji chi square menunjukkan tidak ada hubungan antara keberadan tanaman hias di

\begin{tabular}{|c|c|c|c|c|c|c|c|}
\hline & & \multicolumn{4}{|c|}{ Keberadaan jentik Ae.aegypti } & \multirow{2}{*}{ Nilai $P$} & \multirow{2}{*}{ OR $(95 \% C I)$} \\
\hline & & \multicolumn{2}{|c|}{ Iya } & \multicolumn{2}{|c|}{ Tidak } & & \\
\hline & & $\mathrm{n}$ & $\%$ & $\mathrm{n}$ & $\%$ & \multirow{3}{*}{0,561} & \multirow{3}{*}{$\begin{array}{c}1,275(0,562- \\
2,890)\end{array}$} \\
\hline \multirow{2}{*}{ Tanaman hias } & Iya & 25 & $42 \%$ & 34 & $58 \%$ & & \\
\hline & Tidak & 15 & $37 \%$ & 26 & $63 \%$ & & \\
\hline
\end{tabular}

lingkungan rumah dengan keberadaan jentik Ae.aegypti di Desa Way Kandis Bandar Lampung (nilai $p$ sebesar 0,561 . OR $=1,275$ ). Nilai $P$ yang didapat 0,561 yaitu tidak signifikan karena Nilai $P>0,05$ maka HO diterima dan Ha ditolak. Menurut pendapat peneliti pot tanaman hias di pekarangan rumah warga di lingkungan desa Way Kandis tidak terdapat keberadaan jentik dikarenakan letak dari pot tersebut searah dengan keberadaan sinar matahari yang membuat pot tersebut kering dan tidak memiliki genangan air.

Penelitian ini sejalan dengan Siahaan dkk (2019) "Studi Kepadatan Jentik Nyamuk Di Kelurahan Tebing Tinggi Kecamatan Tebing Tinggi Kabupaten Tanjung Jabung Barat Jambi Tahun 2019" " dari hasil uji statistik nilai $p$ value 1,00 Bahwa pada pot bunga di luar rumah tidak ditemukan jentik Ae.agypti, tetapi jentik banyak ditemukan pada drum bekas dikarenakan memiliki penampungan air lebih banyak. 
Tabel 2. Analisis keberadaan genangan air di lingkungan rumah dengan keberadaan jentik Ae.aegypti

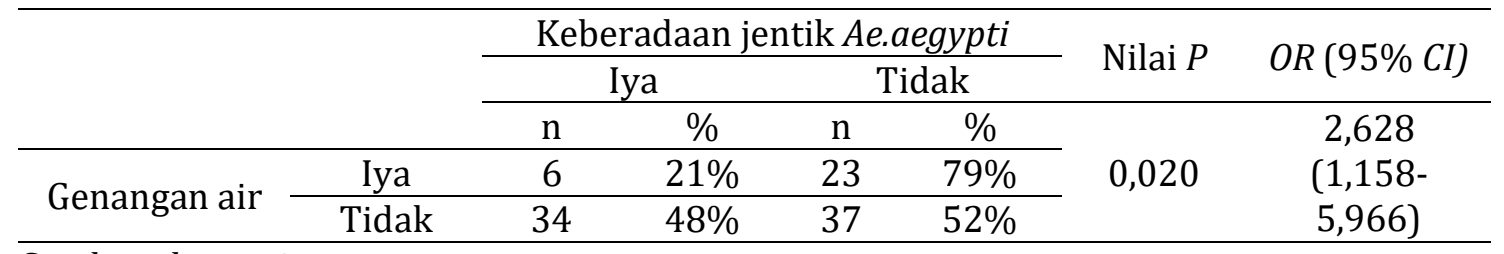

Sumber: data primer

Hasil uji chi square menunjukkan ada hubungan antara genangan air di lingkungan rumah dengan keberadaan jentik Ae.aegypti di Desa Way Kandis Bandar Lampung (nilai $p$ sebesar 0,020 . $\mathrm{OR}=2,628$ ). Nilai $P$ yang didapat 0,020 yaitu signifikan karena Nilai $P<0,05$ dapat diartikan bahwa keluarga yang di lingkungan rumahnya terdapat genangan air mempunyai risiko terdapatnya jentik di rumahnya 2,628 kali lebih besar dibanding dengan keluarga yang di lingkungan rumahnya tidak terdapat genangan air, maka Ha diterima HO ditolak.

Menurut pendapat peneliti di lingkungan tempat tinggal masyarakat desa Way Kandis 29 dari 100 rumah, terdapat genangan air seperti air selokan, genangan air di ember dan kontainer dispenser dan jentik Ae.aegypti dapat hidup di genangan air tersebut. Banyaknya genangan air disuatu lingkungan rumah mengakibatkan besarnya keberadaan suatu jentik di lingkungan tersebut. Nyamuk Ae.aegypti mengalami metamorfosa sempurna, yaitu dari bentuk telur, jentik, pupa dan nyamuk dewasa. Stadium telur, jentik, dan pupa hidup di dalam air (aquatik), sedangkan nyamuk hidup secara teresterial (di udara bebas). Pada umumnya telur akan menetas menjadi jentik dalam waktu kira-kira 2 hari setelah telur terendam air (Jacob,dkk).

Genangan air dapat diklasifikasikan dalam beberapa kelompok yang didasarkan pada ukuran, lamanya genangan air (tetap atau sementara) dan macam tempat air. Kelompok genangan air besar yang sifatnya sementara atau tetap diantaranya adalah rawa, danau, sawah, genangan air hujan, kubangan, parit irigasi di sawah, parit atau got buangan air limbah. Kelompok genangan air yang kecil meliputi lubang di pohon, tangki air, ember, kontainer dispenser,sumur dan bak mandi (Depkes RI, 2017). Demikian pula hasil penelitian Jacob dkk (2015) "Hubungan Karakteristik Sumur Gali dengan Keberadaan Jentik Nyamuk Ae aegypti di Kelurahan Bendan Ngisor, Kecamatan Gajahmungkur Kota Semarang" dari hasil uji statistik nilai $p$ value 0,02 menyatakan bahwa jentik Ae.aegypti mampu hidup di air jernih.

Tabel 3. Analisis keberadaan jarak antar rumah 40-100 m di lingkungan rumah dengan keberadaan jentik Ae.aegypti

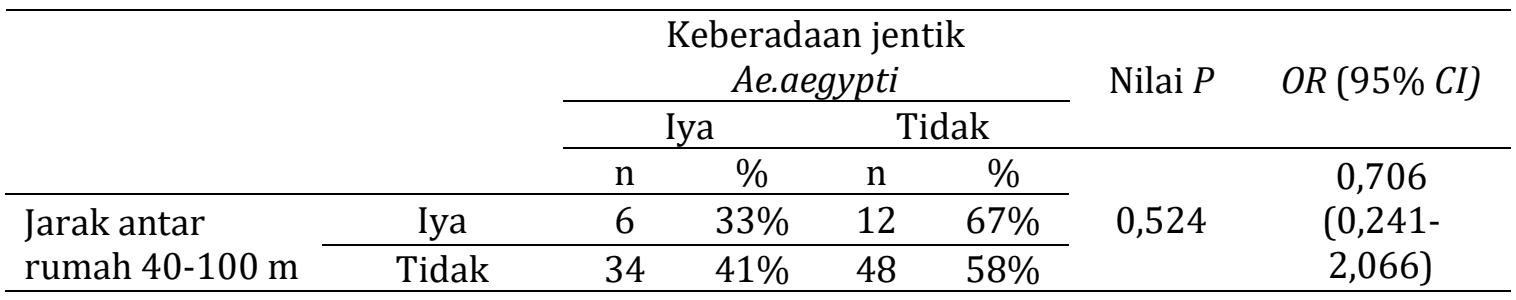

Sumber : data primer

Hasil uji chi square menunjukkan tidak ada hubungan antara jarak antar rumah 40-100 m di lingkungan rumah dengan keberadaan jentik Ae.aegypti di Desa Way Kandis Bandar Lampung (nilai $p$ sebesar 0,524 . OR $=0,706$ ). Nilai $P$ yang didapat 0,524 yaitu tidak signifikan karena Nilai $P>0,05$ maka H0 diterima dan Ha ditolak. 
Menurut pendapat peneliti sebanyak 82 rumah berjarak dengan rumah berikutnya kurang dari $1 \mathrm{~m}$, lingkungan luar rumah yang bersih tidak terdapat genangan air dan tidak ditemukannya banyak barang yang menumpuk merupakan faktor pendukung untuk tidak ditemukannya jentik dirumah tersebut. Nyamuk betina Ae.agypti senang meletakkan telurnya dengan jarak terbang 40-100 m, karena jarak terbang nyamuk yang mencapai 100 meter menyebabkan nyamuk mudah berpindah pada jarak 5 meter (Apriliana,2017). maka dari itu tidak ditemukan hubungan keberadaan jentik dengan jarak rumah 40-100 $\mathrm{m}$.

Penelitian ini sejalan dengan Apriliana (2017) dalam "Hubungan Kondisi Lingkungan Dengan Kejadian Demam Berdarah Dengue (DBD) Pada Keluarga Di Gagakan Kecamatan Sambong Kabupaten Blora Tahun 2017" uji statistik nilai $p$ value 0,588 bahwa tidak adanya hubungan antara jarak antar rumah dengan kejadian DBD. Keberadaan jentik dan nyamuk Ae.aegypti tidak memiliki hubungan dengan jarak antar rumah 40-100 m.

Tabel 4. Analisis kebiasaan menggantung pakaian di lingkungan rumah dengan keberadaan jentik Ae.aegypti

\begin{tabular}{|c|c|c|c|c|c|c|c|}
\hline & & \multicolumn{4}{|c|}{$\begin{array}{c}\text { Keberadaan jentik } \\
\text { Ae.aegypti }\end{array}$} & \multirow[t]{2}{*}{ Nilai $P$} & \multirow[t]{2}{*}{ OR $(95 \% C I)$} \\
\hline & & \multicolumn{2}{|c|}{ Iya } & \multicolumn{2}{|c|}{ Tidak } & & \\
\hline & & $\mathrm{n}$ & $\%$ & $\mathrm{n}$ & $\%$ & \multirow{3}{*}{0,248} & \multirow{3}{*}{$\begin{array}{c}0,622(0,277 \\
1,396)\end{array}$} \\
\hline \multirow{2}{*}{$\begin{array}{c}\text { Kebiasaan } \\
\text { menggantung } \\
\text { pakaian }\end{array}$} & Iya & 20 & $35 \%$ & 37 & $65 \%$ & & \\
\hline & Tidak & 20 & $46 \%$ & 23 & $53 \%$ & & \\
\hline
\end{tabular}

Sumber: data primer

Hasil uji chi square menunjukkan tidak ada hubungan antara kebiasaan menggantung pakaian di lingkungan rumah dengan keberadaan jentik Ae.aegypti di Desa Way Kandis Bandar Lampung (nilai p sebesar 0,248 . $O R=0,622$ ). Nilai $P$ yang didapat 0,248 yaitu tidak signifikan karena Nilai P >0,05 maka H0 diterima dan Ha ditolak.

Menurut pendapat peneliti sebanyak 57 rumah memiliki kebiasaan menggantung pakaian di dalam rumah, dan juga kondisi dalam rumah masyarakat desa Way Kandis terkena paparan sinar matahari yang dapat dikatakan kondisi rumah tersebut tidak lembab, siklus hidup jentik Ae.aegypti memerlukan media air untuk berubah menjadi nyamuk dewasa, sedangkan kebiasaan menggantung pakaian tidak berhubungan dengan siklus hidupnya jentik Ae.aegypti maka dari itu tidak terdapat hubungan yang bermakna antara keberadaan kawat kasa dengan keberadaan jentik Ae.aegypti.

Penelitian ini sejalan dengan Nilawati (2015) dalam "Pelaksanaan 3M dengan keberadaan jentik Ae.aegypti di wilayah Kerja Puskesmas Bekasi” dari hasil uji statistik nilai $p$ value 0,387 yang artinya tidak terdapat hubungan yang bermakna antara kebiasaan menggantung pakaian dengan keberadaan jentik Ae.aegypti.

Tabel 5. Analisis keberadaan kawat kasa di lingkungan rumah dengan keberadaan jentik Ae.aegypti

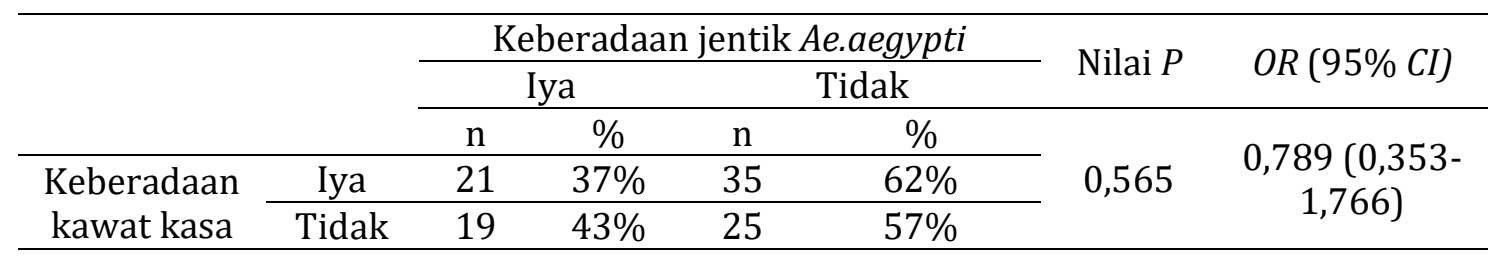

Sumber: data primer 
Hasil uji chi square menunjukkan tidak ada hubungan antara keberadaan kawat kasa di lingkungan rumah dengan keberadaan jentik Ae.aegypti di Desa Way Kandis Bandar Lampung (nilai $\mathrm{p}$ sebesar 0,565. OR $=0,789$ ). Nilai $\mathrm{P}$ yang didapat 0,565 yaitu tidak signifikan karena Nilai P >0,05 maka H0 diterima dan Ha ditolak.

Menurut pendapat peneliti sebanyak 56 dari total 100 rumah yang terdapat keberadaan kawat kasa dan terdapat keberadaan jentik Ae.aegypti. Berdasarkan hasil pengamatan di lingkungan desa Way Kandis rumah yang telah memakai kawat kasa, di rumah tersebut setiap lubang ventilasinya tidak ditutupi oleh kawat kasa kebanyakan di ventilasi kamar nya saja. Siklus hidup jentik Ae.aegypti memerlukan media air untuk berubah menjadi nyamuk dewasa, sedangkan kawat kasa sendiri tidak berhubungan dengan siklus hidupnya jentik maka dari itu tidak terdapat hubungan yang bermakna antara keberadaan kawat kasa dengan keberadaan jentik Ae.aegypti.

Penelitian ini sejalan dengan Nilawati (2015) dalam “ Pelaksanaan 3M dengan keberadaan jentik Ae.aegypti di wilayah Kerja Puskesmas Bekasi" dari hasil uji statistik nilai p value 0,095 yang artinya tidak terdapat hubungan yang bermakna antara keberadaan kawat kasa dengan keberadaan jentik Ae.aegypti.

\section{Simpulan dan Saran}

Diketahui bahwa terdapat $60 \%$ rumah yang tidak terdapat jentik Aeaegypti, sedangkan 40\% rumah terdapat jentik Ae.aegypti. Diketahui bahwa terdapat $41 \%$ rumah yang tidak terdapat tanaman hias, sedangkan 59\% rumah terdapat tanaman hias. Diketahui bahwa terdapat $71 \%$ rumah yang tidak terdapat genangan air,sedangkan $29 \%$ rumah terdapat genangan air. Diketahui bahwa terdapat 82\% rumah yang jarak antar rumah tidak 40-100 m, sedangkan $18 \%$ rumah jarak antar rumah 40-100 m. Diketahui bahwa terdapat $43 \%$ rumah yang tidak terdapat kebiasaan menggantung pakaian, sedangkan 57\% rumah terdapat kebiasaan menggantung pakaian. Diketahui bahwa terdapat $44 \%$ rumah yang tidak terdapat pemakaian kawat kasa, sedangkan 56\% rumah terdapat pemakaian kawat kasa. Diketahui kepadatan jentik Aeaegypti berdasarkan house index sebesar $40 \%$. Terdapat hubungan signifikan genangan air dengan keberadaan jentik Ae.aegypti sedangkan keberadaan tanaman hias, jarak antar rumah, kebiasaan menggantung pakaian dan keberadaan kawat kasa tidak terdapat hubungan signifikan dengan keberadaan jentik Ae.aegypti. Untuk peneliti selanjutnya disarankan mencari lokasi endemis lainnya di Bandar Lampung berdasarkan data tertinggi dari Badan Pusat Statistik dengan memperhatikan variabel lainnya yang dapat memperberat dan meningkat nya keberadaan jentik Ae.aegypti

\section{Daftar Rujukan}

Adifian, Ishak, H., \& Ane, R. La. (2019). Kemampuan adaptasi nyamuk aedes aegypti dan aedes albopictus dalam berkembang biak berdasarkan jenis air. Applied Surface Science, 467-468, 640-647.

Cecep, D.S. (2011). Vektor Penyakit Tropis. Yogyakarta: Gosyen.

Dermala, S. (2012). Kejadian Demam Berdarah Dengue. Jakarta: EGC.

Dinas Kesehatan Provinsi Lampung. (2015). Profil Kesehatan Provinsi Lampung Tahun 2015. Lampung.

Fitriana, B., \& Yudhastuti, R. (2018). Hubungan Faktor Suhu Dengan Kasus Demam Berdarah Dengue (Dbd) Di Kecamatan Sawahan Surabaya. The Indonesian Journal Of Public Health, 13(1), 83-94. 
Hidayati, yuli. (2013). Hubungan Antara Tempat Perkembangan Nyamuk Aedes aegypti Kasus Demam Berdarah Dengue Di Kecamatan Rajabasa Bandar Lampung. Journal of Chemical Information and Modeling, 53(9), 1689-1699.

Jacob, N. \& Dita, K. (2015). Epidemiologi Demam Berdarah Dengue. Jakarta: EGC.

Mayasari. (2018). Determinan Kejadian Demam Berdarah Dengue (Dbd) Di Kecamatan Medan Tembung. Jurnal Kesehatan Pena Medika, 8(2010), 9-25.

Natadisastra, D. \& Agoes, R. (2014). Parasitologi Kedokteran Ditinjau dari Organ Tubuh yang Diserang. Jakarta: EGC.

Nilawati. (2015). Pelaksanaan 3M Dengan Keberadaan Jentik Ae.Aegypti Di Wilayah Kerja Puskesmas Bekasi. Jurnal Universitas Muhammadiyah Jakarta, 2(2), 20-25.

Siahaan, S., \& Fauziah, R. (2020). Studi Kepadatan Jentik Nyamuk di Kelurahan Tebing Tinggi Kecamatan Tebing Tinggi Kabupaten Tanjung Jabung Barat Jambi Tahun 2019. Jurnal Ilmiah Universitas Batanghari Jambi, 20(1), 302.

Susanti, S., \& Suharyo, S. (2017). Hubungan Lingkungan Fisik Dengan Keberadaan Jentik Aedes Pada Area Bervegetasi Pohon Pisang. Unnes Journal of Public Health, 6(4), 271-276.

Widoyono. (2011). Penyakit Tropis: Epidemiologi, Penularan, Pencegahan \& Pemberantasan. 2 ed. Jakarta: Erlangga.

Wijirahayu, S., \& Sukesi, T. W. (2019). Hubungan Kondisi Lingkungan Fisik dengan Kejadian Demam Berdarah Dengue di Wilayah Kerja Puskesmas Kalasan Kabupaten Sleman. Jurnal Kesehatan Lingkungan Indonesia, 18(1), 19. 